\title{
PROSES PENYERAPAN BAHASA INGGRIS KE DALAM BAHASA JEPANG: (KAJIAN FONOLOGI GENERATIF TRANSFORMASIONAL)
}

\author{
Muslihah \\ Magister Ilmu Linguistik Universitas Diponegoro \\ muslihah.nazwa@gmail.com
}

\begin{abstract}
Abstrak
Tujuan penelitian ini adalah untuk menjelaskan proses-proses fonologis dan kaidah fonologi kata serapan bahasa asing ke dalam bahasa Jepang melalui kajian fonologi generatif transformasional.Penelitian ini menggunakan metode deskriptif kualitatif.Sumber data diperoleh dari sumber tertulis yaitu berupa kata-kata yang berasal dari kamus kata serapan bahasa Jepang. Hasil penelitian ini yaitu diketahui terdapat 7 proses fonologi yang terjadi pada proses penyerapan kata bahasa Inggris ke dalam bahasa Jepang adalah sebagai berikut : (1) proses penambahan segmen /u/ di akhir kata, (2) penambahan segmen /o/ di akhir kata, (3) penambahan segmen /u/ di tengah kata, (4) penambahan segmen /o/ ditengah kata, (5) subsitusi fonem /l/ menjadi /r/, (6) subsitusi fonem /v/ menjadi /b/, (7)Penambahan segmen /i/, (8) Substitusi fonem /t/ menjadi fonem /c/. Proses perubahan fonologis pada penyerapan bahasa Inggris ke dalam bahasa Jepang terjadi dipengaruhi oleh faktor internal yaitu perbedaan sistem fonologi yang terdapat dalam bahasa Inggris dan bahasa Jepang.
\end{abstract}

Kata Kunci: bahasa Jepang; kata serapan; proses fonologis; fonologi generatif

\begin{abstract}
(Title: The Analysis of Loan Words of English Language Transformed into Japanese Language (Study of Generative Transformational Phonological) The aims of this research are to explain the phonological processes and phonological rule in loan words of English language into Japanese language through generative phonological studies. This research used qualitative descriptive method. The research data are taken from Japanese dictionary loan words. The result shows eight phonological processes and phonological rules in the process of transformation English language to Japanese. (1) the process of adding segment $/ u /$ at the end of the words (2) segment additions /o/ at the end of the words (3) segment additions $/ u /$ in the middle of words (4) segment additions $/ o$ / in the middle of words (5) substitution of phoneme $/ l /$ to $/ r /$, (6) substitution of phoneme $/ v /$ to $/ b /$, (7) segment additions $/ i /$, (8) substitution of phoneme $/ t /$ to $/ \mathrm{c} /$. The transformation of phonological processes on the loan words of English language into Japanese language affected by the internal factor.
\end{abstract}

Keywords: Japanese; loan words; phonologicalprocesses; generative phonological

\section{PENDAHULUAN}

\section{Latar Belakang}

Gairaigo (外来語) ialah istilah yang digunakan dalam bahasa Jepang untuk menyebutkan kosakata serapan yang berasal dari bahasa Eropa terutama dari bahasa Inggris (Inggris-Amerika) (Sunarni dan Johana, 2010: 65). Kata gairaigo berasal dari kata gai (外) yang berarti luar, rai (来) yang berarti datang dan go(語) 
yang berarti kata, sehingga diterjemahkan menjadi kata yang datang dari luar. Bahasa Jepang sangat terkenal dengan banyaknya huruf, namun memiliki sedikit sekali bunyi bahasa. Sehingga bahasa Jepang banyak meminjam atau mengadopsi kosa kata terutama dari negara-negara Eropa.Dalam bahasa Jepang, kata-kata dari bahasa asing mudah dikenali karena biasanya ditulis dalam huruf katakana. Oleh karena itu, gairaigo juga disebut katakana-go (kata katakana). Misalnya seperti kata bahasa Inggris milk yang berarti 'susu' akan menjadi ミルク [miruku], dan note yang berarti 'buku catatan' menjadi $ノ-1$ [nooto] mengalami perubahan bunyi setelah diadaptasi ke dalam sistem fonologi bahasa Jepang.

Beberapa penelitian mengenai kata serapan bahasa bahasa Jepang (BJ) ataupun mengenai proses fonologi pada bahasa-bahasa di dunia sudah banyak dilakukan oleh peneliti sebelumnya. Adapun penelitian kata serapan bahasa Jepang pernah dilakukan oleh Giovanni (2013) dengan penelitiannya yang berjudul "analisis perubahan makna kata-kata serapan (gairaigo) bahasa Jepang yang berasal dari bahasa Inggris".Penelitiannya menyebutkan bahwa gairaigo mengalami perubahanan makna termasuk dalam kelas kata nomina, adjektiva, penyempitan makna, perluasan makna, dan pengasaran makna.

Kemudian penelitian Nafisah (2017), penelitiannya membahas mengenai proses fonologi dari berbagai bahasa dengan kajian fonologi generatif. Hasil penelitiannya yaitu dikatakan bahwa proses fonologis pada dasarnya adalah proses berubahnya bunyi kata atau frase karena adanya proses perubahan bunyi dari bentuk dasar ke bentuk turunan. Perubahan tersebut biasanya diakibatkan oleh afiksasi.Penelitian oleh Perwira (2016) yaitu tentang proses penyerapan bahasa Belanda ke dalam bahasa Jawa yang samasama dikaji menggunakan kajian fonologi generatif. Penelitiannya tersebut ditemukan 16 kaidah yang terdapat dalam proses fonologis kata yang diserap dari bahasa Belanda ke dalam bahasa Jawa.

Sistem fonologi bahasa Inggris berbeda dengan sistem fonologi yang ada dalam bahasa Jepang. Berdasarkan sistem tersebut ada beberapa fonem yang tidak dapat diterima dalam bahasa Jepang. Oleh karena itu kata-kata yang diadaptasi dari bahasa Inggris akan menyesuaikan dengan sistem yang ada pada bahasa Jepang. Sehingga menyebabkan terjadinya perubahan bunyi yang bertujuan untuk mempermudah pelafalan.Fonologi merupakan ilmu yang mempelajari bunyi bahasa, sehingga dalam hal ini fonologi merupakan kajian yang tepat untuk mengamati perubahan bunyi pada kata serapan bahasa Inggris ke dalam bahasa Jepang pada penelitian ini.

Berdasarkan uraian di atas perbedaan penelitian ini dengan penelitian terdahulu adalah pada teori, fokus, dan objek yang diteliti. Pada penelitian pertama yaitu memfokuskan pada kajian semantik atau makna yang terbentuk dari kata serapan bahasa Inggris ke bahasa Jepang. Sedangkan perbedaan dengan penelitian kedua yaitu pada objek penelitian. Pada penelitian sebelumnya yaitu kata serapan dari bahasa Belanda ke bahasa Jawa. Sehingga penelitian ini dirasa memiliki nilai kebaharuan dalam kajian linguistik ke depannya khususnya pada bidang fonologi. Peneliti akan memaparkan mengenai bentuk-bentuk serta proses fonologi pada kata serapan bahasa Inggris ke dalam bahasa Jepang.

\section{Sistem Fonologi Bahasa Jepang}

Huruf vokal dalam bahasa Jepang ada lima buah, yaitu あ、い、う、え、お。 Bunyi vokal tersebut jika dituliskan dengan transkripsi fonetisnya maka akan menjadi [a], [i], [u], [e], dan [o]. Perbedaan bunyi vokal dalam bahasa 
Izumi, Volume 7 No 2, 2018

e-ISSN: 2502-3535, p-ISSN: 2338-249X

Tersedia online di http://ejournal.undip.ac.id/index.php/izumi

Inggris dengan bahasa Jepang yaitu vokal /u/ dengan lambang fonetik [u], karena vokal /u/ dalam bahasa Jepang diucapkan dengan bentuk bibir tidak bulat, sedangkan dalam bahasa Inggris pada umumnya diucapkan dengan bentuk bibir bulat. Huruf konsonan dalam bahasa Jepang secara fonemik terdiri dari konsonan $/ \mathrm{k} /$, $/ \mathrm{g} /, / \mathrm{s} /, / \mathrm{z} /, / \mathrm{t} /, / \mathrm{d} /, / \mathrm{n} /, / \mathrm{h} /, / \mathrm{b} /, / \mathrm{p} /, / \mathrm{m} /, \mathrm{r} /$ $\operatorname{dan} / \mathrm{N} /$.
Fonem dalam bahasa Jepang dibedakan atas vokal (V), konsonan (C), dan semi vokal (Sv).Sistem fonologi bunyi bahasa Jepang ada yang termasuk ke dalam fonem, dan ada pula yang termasuk ke dalam alofon. Jenis fonem yang terdapat dalam bahasa Jepang terdiri dari empat macam seperti berikut: (a) Vokal : /a, i, u, e, o/ (b) Konsonan : / k, g, s, z, t, d, c, n, h, $\mathrm{p}, \mathrm{b}, \mathrm{m}, \mathrm{r} /$. (c) Semi vokal : /w, j/, (d) Fonem Khusus : /Q, N, R /.
Fonem（音素）

a. /s/

b. $/ \mathrm{z} /$

c./t/

d./d/

e. $/ \mathrm{n} /$

f./h/

g. /N/ (ン)
Alofon（異音）

$[\mathrm{s}]+[\mathrm{a}, \mathrm{w}, \mathrm{e}, \mathrm{o}]$

$\left[\int\right]+[\mathrm{i}]$

$[\mathrm{z}]+[\mathrm{a}, \mathrm{w}, \mathrm{e}, \mathrm{o}]$

$[3]+[\mathrm{i}]$

$[\mathrm{t}]+[\mathrm{a}, \mathrm{e}, \mathrm{o}]$

$[\mathrm{t} 6]+[\mathrm{i}]$

$[\mathrm{ts}]+[\mathrm{w}]$

$[\mathrm{d}]+[\mathrm{a}, \mathrm{e}, \mathrm{o}]$

[d] $+[\mathrm{i}]$

$[\mathrm{dz}]+[\mathrm{w}]$

$[\mathrm{n}]+[\mathrm{a}, \mathrm{w}, \mathrm{e}, \mathrm{o}]$

$[\mathrm{n}]+[\mathrm{i}]$

$[\mathrm{h}]+[\mathrm{a}, \mathrm{e}, \mathrm{o}]$

$[\mathrm{c}]+[\mathrm{i}]$

$[\varphi]+[\omega]$

$[\mathrm{m}]+[\mathrm{p}, \mathrm{b}, \mathrm{m}]$

さんぽー[sampo]

かんばん［kamban]

あんみん［ammin]

$[\mathrm{n}]+[\mathrm{t}, \mathrm{d}, \mathrm{ts},(\mathrm{dz}), \mathrm{t}, \mathrm{d}, \mathrm{z}, \mathrm{n}, \mathrm{r}]$

反対资antai]

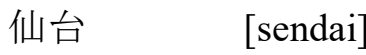

$[\mathrm{n}]+[\mathrm{n}]$

こんにゃく [konnaku]

$[\mathrm{y}]+[\mathrm{k}, \mathrm{g}, \mathrm{y}]$

けんか

[kejka] 


$$
\begin{aligned}
& \text { あんがい [aynai] } \\
& {[\mathrm{N}]+[\cdot \mathrm{N}] \text { 本 }[\mathrm{hoN}]} \\
& {[\tilde{\mathrm{u}}]+[\mathrm{a}, \mathrm{o}, \mathrm{u}, \mathrm{w}, \mathrm{s}, \mathrm{z}, \mathrm{3}, \mathrm{J}]} \\
& \begin{array}{ll}
\text { 電話 } & \text { [denwa] } \\
\text { 恋愛 } & \text { [ren-ai] }
\end{array}
\end{aligned}
$$

h. /Q/ (ッ)

$\begin{array}{lll}{[\mathrm{p}]+[\mathrm{p}]} & \text { いっぱい } & {[\text { ippai }]} \\ {[\mathrm{t}]+[\mathrm{t}]} & \text { いった } & {[\text { ittai }]} \\ {[\mathrm{t}]+[\mathrm{ts}]} & \text { いっつう } & {[\text { ittsu }]} \\ {[\mathrm{t}]+[\mathrm{t}]} & \text { ばっちり } & {[\text { batchiri] }} \\ {[\mathrm{s}]+[\mathrm{s}]} & \text { ふっそう } & {[\text { bessou }]} \\ {[f]+[f]} & \text { いっしょう } & {[\text { isshou }]} \\ {[\mathrm{k}]+[\mathrm{k}]} & \text { いっかい } & {[\text { ikkai }]}\end{array}$

Fonologi generatif pertama kali diperkenalkan oleh Noam Chomsky dalam bukunya yang berjudul syntactic Structure (1957). Dalam buku tersebut dibahas mengenai proses pembentukan kalimat. Chomsky menjelaskan bahwa dalam proses pembentukkan kalimat yaitu harus melewati tiga proses yaitu yang pertama adalah rumus struktur frase, rumus transformasi, dan rumus morfofonemik (Yusuf, 1998: 92). Di dalam kajian fonologi generatif yang digagas oleh Chomsky, secara umum yaitu membahas mengenai proses fonologi, sehingga di dalamnya terdapat kaidah-kaidah penyusun dalam sebuah proses perubahan bunyi pada proses fonologi bahasa.

Schane (1992: 51-62) menyatakan bahwa, proses fonologi ialah suatu proses di mana adanya perubahan bunyi bahasa yang disebabkan oleh beberapa cara, yaitu akibat adanya proses asimilasi, pelesapan, pelemahan dan penguatan dalam struktur silabel, netralisasi, dan metatesis. Ketika morfem-morfem bergabung untuk membentuk kata, segmen-segmen dari morfem yang berdekatan terkadang mengalami suatu perubahan itulah yang disebut dengan proses fonologi bahasa.

\section{Fitur Distingtif}

Yusuf (1998: 77) berpendapat bahwa jika unit dasar fonologi adalah distingtif fitur, maka fonem adalah unsur segmentasi yang terdiri dari serangkain ciri distingtif. Ciri-ciri pembeda sebuah segmen dalam fonologi generatif didasarkan pada (1) ciri fitur kelas utama (silabis, sonoran, konsonantal); (2) ciri daerah artikulasi (anterior, koronal); (3) ciri cara artikulasi (kontinuan, penglepasan tertunda, striden, nasal, lateral); (4) batang lidah (tinggi, rendah, belakang); (5) bentuk bibir (bulat); (6) tambahan (tegang, bersuara, aspirasi, glotalisasi); dan (7) prosodi (tekanan dan panjang) (Schane, 1992: 28-35). Berdasarkan hal tersebut dapat dipahami bahwa terdapat satuan bahasa yang lebih kecil dari fonem yang bisa dijelaskan melalui fitur distingtif.Sehingga fitur distingtif berfungsi untuk mengetahui unit terkecil dalam analisis bunyi bahasa.

\section{Kaidah Fonologi Generatif}

Kaidah fonologi dapat dirumuskan ketika kita dapat dengan tepat menentukkan syarat terjadinya perubahan suatu bunyi bahasa. Jika kita sudah mampu akan hal tersebut berarti kita juga dapat memberikan suatu kaidah pada proses fonologi yang terjadi. Oleh karena itu Schane menjelaskan (1992), jika kita ingin mengelompokan rumus-rumus fonologi yaitu dapat dilakukan dengan mengamati gejala perubahan bunyi pada suatu bahasa, yaitu antara lain pelepasan segmen (deletion) dan penambahan segmen (addition), permutasi (permutation), perubahan urutan 
segmen (metathesis), perubahan ciri distingtif segmen (feature change), asimilasi dan disimilasi, penyatuan segmen (coalescence).

\section{METODE PENELITIAN}

Penelitian ini merupakan jenis penelitian deskriptif dengan pendekatan kualitatif. Penggunaan metode kualitatif karena data yang diteliti adalah berupa kata yang mengalami proses fonologi atau perubahan bunyi bahasa kata serapan bahasa asing ke dalam bahasa Jepang. Adapun beberapa tahapan penelitian ini adalah sebagai berikut :

\section{Tahap Pengumpulan Data}

Penelitian ini menggunakan metode studi pustaka, karena data yang diteliti berupa kata-kata serapan yang diperoleh dari sumber tertulis yaitu dari kamus kata serapan bahasa Jepang karya Bachtiar Harahap. Data-data kata serapan dari kamus tersebut dipilih yang termasuk ke kata serapan yang berasal dari bahasa Inggris.

\section{Tahap Analisis Data}

Setelah data telah terkumpul dari proses pengumpulan data yang sudah dilakukan, tahapan selanjutnya adalah proses penganalisisan data. Data dianalisis secara sistematis dan dideskripsikan menggunakan kaidah-kaidah fonologi generatif serta fitur distingtif.

\section{Tahap Penyajian Data}

Tahap ini merupakan tahap akhir setelah selesai menganalisis data yang diperoleh. Hasil dari penelitian ini adalah sebuah paparan mengenai proses fonologi yang terjadi pada kata-kata bahasa Inggris yang diserap ke dalam bahasa Jepang.

\section{HASIL DAN PEMBAHASAN}

Berikut ini akan dijelaskan bagaimana proses terjadinya perubahan bunyi yang dikaji menggunakan kajian fonologi generatif. Proses fonologis tersebut terdiri dari perubahan segmen berupa penambahan segmen, dan subtitusi.

\begin{tabular}{|c|c|c|c|c|}
\hline \multicolumn{2}{|c|}{ Bahasa Inggris } & \multicolumn{2}{|c|}{ Bahasa Jepang } & Arti \\
\hline Keyword & [ki:wə:d] & キーワード & [kiiwaado] & 'kata kunci' \\
\hline Standard & [standərd] & スタンダード & [sutandaado] & 'standar' \\
\hline Interest & [intərist] & インテレスト & [interesuto] & 'menarik' \\
\hline Giant & [dzaint] & ジャイアント & [zaianto] & 'raksasa' \\
\hline Support & [sə:port] & サポート & [sapooto] & 'mendukung' \\
\hline Present & [prezənt] & プレゼント & [purezento] & 'hadiah' \\
\hline
\end{tabular}


Izumi, Volume 7 No 2, 2018

e-ISSN: 2502-3535, p-ISSN: 2338-249X

Tersedia online di http://ejournal.undip.ac.id/index.php/izumi

\begin{tabular}{|c|c|c|c|c|}
\hline \multicolumn{2}{|c|}{ Bahasa Inggris } & \multicolumn{2}{|c|}{ Bahasa Jepang } & Arti \\
\hline type & [taip] & タイプ & [taipu] & 'jenis' \\
\hline address & [adres] & アドレス & [adoresu] & 'alamat' \\
\hline space & [speis] & スペス & [supesui] & 'ruang' \\
\hline dress & [dres] & ドレス & [doresuu] & 'gaun' \\
\hline mechanism & [mekənizem] & メカニズ & [mekanizumu ] & 'mekanisme' \\
\hline gram & [gram] & グラム & [guramu] & 'gram' \\
\hline system & [sistəm] & システム & [shisutemui] & 'sistem' \\
\hline golf & [golf] & ゴルフ & [gorufü] & 'golf' \\
\hline Life & [laif] & ライフ & [raifu] & 'kehidupan' \\
\hline
\end{tabular}

Data 2

\begin{tabular}{|c|c|c|c|c|}
\hline \multicolumn{2}{|c|}{ Bahasa Inggris } & \multicolumn{2}{|c|}{ Bahasa Jepang } & Arti \\
\hline Drama & [dramə] & ドラマ & dorama & 'drama' \\
\hline Trend & [trend] & トレンド & torendo & 'gaya' \\
\hline Intro & [intro] & イントロ & Intoro & 'intro' \\
\hline introduction & [intrəd $\Lambda$ ksyən] & イントロダク & intorodakushon & 'pendahuluan' \\
\hline
\end{tabular}

Data 3

\begin{tabular}{|c|c|c|c|c|}
\hline \multicolumn{2}{|c|}{ Bahasa Inggris } & \multicolumn{2}{|c|}{ Bahasa Jepang } & Arti \\
\hline Glass & [glæs] & グラス & [gurasu] & 'kaca' \\
\hline Grape & [gresp] & グレプ & [gurspu] & 'anggur' \\
\hline prototype & [proutətaip] & プレトタイプ & [purototaipu] & 'prototipe' \\
\hline Fact & [fækt] & ファクト & [fakuito] & 'fakta' \\
\hline surprise & [sərpraIz] & スプライズ & [supuraizu] & 'kejutan' \\
\hline Brake & [breik] & ブレキ & [burrki] & 'rem' \\
\hline Black & [blak] & ブラック & [burak:w] & 'hitam' \\
\hline standard & [standərd] & スタンダード & [sutandaado] & 'standar' \\
\hline
\end{tabular}

Data 4 
Izumi, Volume 7 No 2, 2018

e-ISSN: 2502-3535, p-ISSN: 2338-249X

Tersedia online di http://ejournal.undip.ac.id/index.php/izumi

\begin{tabular}{|c|c|c|c|c|}
\hline \multicolumn{2}{|c|}{ Bahasa Inggris } & \multicolumn{2}{|c|}{ Bahasa Jepang } & Arti \\
\hline Milk & [mil?] & ミルク & [miruku] & 'susu' \\
\hline Install & [instol] & インストル & [insutorw] & 'memasang' \\
\hline Salary & [sæləri] & サラリー & [sararii] & 'gaji' \\
\hline Silver & [silvər] & シルバー & [shiruba] & 'perak' \\
\hline Syllabe & [silabəl] & シラブル & [shiraburur] & 'silabel/suku \\
\hline Life & [laif] & ライフ & [raiful] & 'kehidupan' \\
\hline Club & [klab] & クラブ & [kurabu] & 'kelompok' \\
\hline Ball & [bol] & ボール & [booru] & 'bola' \\
\hline Control & [kəntrol] & コントロー & [kontorooru] & 'kendali' \\
\hline
\end{tabular}

Data 5

\begin{tabular}{|c|c|c|c|c|}
\hline \multicolumn{2}{|c|}{ Bahasa Inggris } & \multicolumn{2}{|c|}{ Bahasa Jepang } & Arti \\
\hline Narrative & [narativ] & ナラチッブ & [naratibur] & 'cerita' \\
\hline Service & [scrvis] & サービス & [saabisu] & 'layanan' \\
\hline Interview & [intervyuw] & インタビュー & [intabyuw] & 'wawancara' \\
\hline Fiber & [farbər] & ファイバー & [faibaa] & 'serat' \\
\hline Survey & [sərvei] & サ—ベイ & [saabei] & 'penyelidika \\
\hline Video & [video] & ビデオ & [bideo] & 'video' \\
\hline interactive & [intəraktiv] & インタラクティ & [intarakutibu & 'Interaktif' \\
\hline
\end{tabular}

Data 6

\begin{tabular}{|c|c|c|c|c|}
\hline \multicolumn{2}{|c|}{ Bahasa Inggris } & \multicolumn{2}{|c|}{ Bahasa Jepang } & Arti \\
\hline Coach & {$[\mathrm{kot}]$} & コーチ & {$[\operatorname{koot} \mathbf{i}]$} & 'pelatih' \\
\hline Lunch & [lantf] & ランチ & [rantfi] & 'makan \\
\hline Touch & [tat'] & タッチ & {$[\operatorname{tat} \mathbf{i}]$} & 'sentuhan' \\
\hline Catch & [katf] & キャッチ & [kyattfi] & 'tangkap' \\
\hline Baggage & [bagij] & バゲージ & [bagecji] & 'bagasi' \\
\hline Charge & [tfarj] & チャージ & [tfaaji] & 'tarif' \\
\hline Page & [peij] & ページ & [pecji] & 'halaman' \\
\hline
\end{tabular}

Data 7 
Izumi, Volume 7 No 2, 2018

e-ISSN: 2502-3535, p-ISSN: 2338-249X

Tersedia online di http://ejournal.undip.ac.id/index.php/izumi

\begin{tabular}{|l|l|l|l|l|}
\hline \multicolumn{2}{|c|}{ Bahasa Inggris } & \multicolumn{2}{c|}{ Bahasa Jepang } & Arti \\
\hline optimistic & {$[$ optimistik $]$} & オプチミスチッ & {$[$ opucimisucikku $]$} & 'optimis' \\
\hline ticket & {$[$ tikit $]$} & チケット & {$[$ ciketto $]$} & 'tiket' \\
\hline team & {$[$ tIm] } & チーム & {$[$ cimu $]$} & 'tim' \\
\hline
\end{tabular}

Data 8

a) Penambahan Segmen /o/ di akhir kata

Dalam sistem fonologi bahasa Jepang, terdapat penambahan fonem /o/ di akhir kata untuk kata-kata yang diserap ke dalam bahasa Jepang yang berfungsi untuk menghindari bunyi konsonan di akhir kata.

Data 1 diatas terdapat penambahan fonem /o/ pada kata bahasa Inggris yang berakhiran konsonan /t/, /d/ dan didahului dengan huruf konsonan sebelumnya. Proses penambahan segmen /o/ di atas terjadi dikarenakan dalam sistem fonologi bahasa Jepang tidak mengenal sistem pelafalan bunyi plosif alveolar di akhir kata. Sehingga menyebabkan fonem /t/, /d/ jika berada di akhir kata dan didahului huruf konsonan maka kata tersebut akan ditambahkan dengan fonem /o/. Proses penambahan segmen tersebut berfungsi untuk menghindari adanya bunyi plosif alveolar pada akhir kata dalam Bahasa Jepang. Kaidah fonologis penambahan segmen tersebut adalah sebagai berikut:

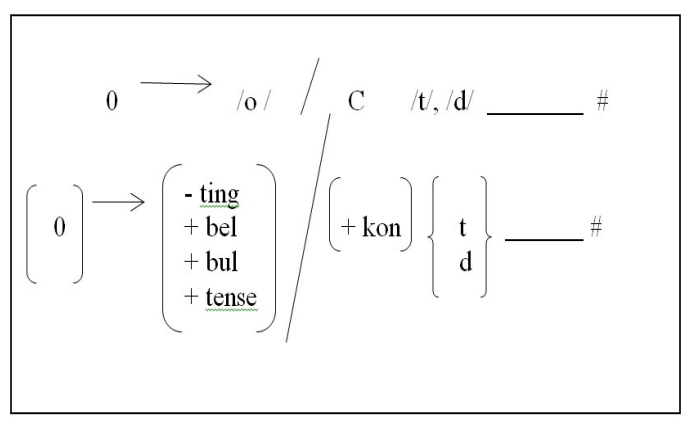

Tabel 1

\section{Keterangan :}

Kaidah pada tabel 1 di atas dapat dijelaskan bahwa terdapat penambahan fonem /o/ di posisi akhir setelah konsonan /t/, dan /d/ yang yang di dahului oleh bunyi konsonan

\section{b) Penambahan segmen $/ \mathbf{u} /$ di akhir kata}

Berdasarkan data ke-2 di atas dapat ketahui bahwa terdapat penambahan fonem $/ \mathrm{u} /$ pada kata yang berakhiran konsonan /s/, /p/, $/ \mathrm{m} /$, /f/, dikarenakan dalam sistem fonologi bahasa Jepang tidak mengenal sistem pelafalan bunyi konsonan di akhir kata kecuali bunyi $/ \mathrm{n} /$. Sehingga menyebabkan fonem $/ \mathrm{s} /, / \mathrm{p} /, / \mathrm{m} /$, , f/ jika berada di akhir kata maka akan ditambahkan dengan fonem $/ \mathrm{u} /$. Proses penambahan segmen tersebut disebut paragog yaitu penambahan segmen diakhir kata yang berfungsi untuk menghindari adanya bunyi konsonan pada akhir kata dalam bahasa Jepang. Proses fonologis penambahan segmen tersebut dapat dilihat sebagai berikut:

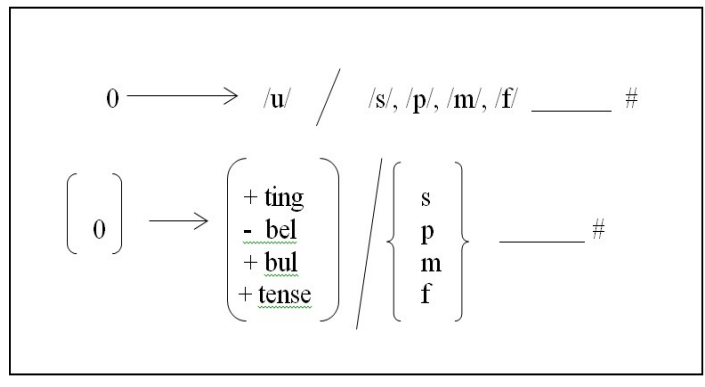

Tabel 2

\section{Keterangan :}

Kaidah pada tabel 2 dapat dijelaskan bahwa terdapat penambahan fonem $/ \mathrm{u} /$ diposisi akhir setelah bunyi konsonan $/ \mathrm{s} /$, $/ \mathrm{p} /, / \mathrm{m} /, / \mathrm{f} /$. 


\section{c) Penambahan Segmen $/ 0 / d i$ tengah kata}

Proses fonologi yang terjadi pada data ke-3 di atas yaitu penyisipan segmen (epentesis) /o/ yang disisipkan atau ditambahkan setelah konsonan /d/ dan /t/ yang berada di tengah kata. Proses penambahan fonem /o/ tersebut hampir sama dengan penambahan fonem /o/ sebelumnya yaitu apabila terdapat fonem /d/ dan /t/ di akhir kata, karena dalam bahasa Jepang dikenal dengan sistem silabel terbuka, sehingga kata yang diadaptasi dari bahasa Inggris ke dalam bahasa Jepang akan menyesuaikan kaidah fonologi yang terdapat dalam bahasa Jepang. Kaidah proses fonologis dari data di atas bisa dilihat di bawah ini:

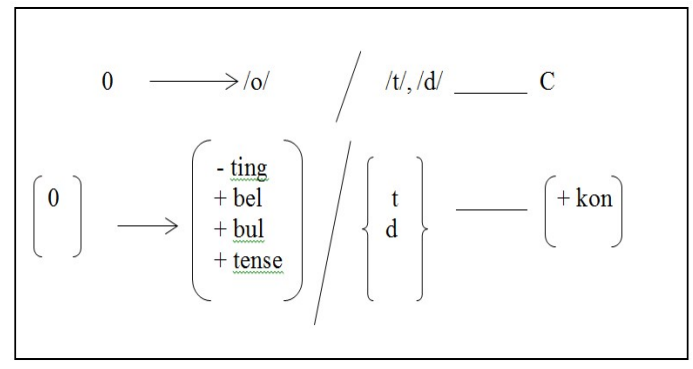

Tabel 3

\section{Keterangan :}

Kaidah pada tabel 3 di atas dapat dijelaskan bahwa terdapat penambahan fonem /o/ setelah bunyi konsonan /t/ dan /d/ yang diikuti bunyi konsonan setelahnya.

\section{d) Penambahan segmen $/ \mathrm{u} / \mathrm{di}$ tengah kata}

Proses penyisipan segmen (epentesis) /u/ pada data 4 di atas adalah salah satu proses fonologi yang terjadi apabila terdapat fonem $/ \mathrm{g} /, / \mathrm{f} /, / \mathrm{p} /, / \mathrm{k} /, / \mathrm{b} /$, /s/ di tengah-tengah kata, proses penambahan fonem $/ \mathrm{u} /$ tersebut hampir sama dengan penambahan fonem /o/ sebelumnya yaitu apabila terdapat fonem /d/ dan /t/ di tengah kata, karena dalam bahasa Jepang dikenal dengan sistem silabel terbuka, sehingga kata yang diadaptasi dari bahasa Inggris ke dalam bahasa Jepang akan menyesuaikan kaidah fonologi yang terdapat dalam bahasa Jepang. Kaidah proses fonologis dari data di atas bisa dilihat di bawah ini:

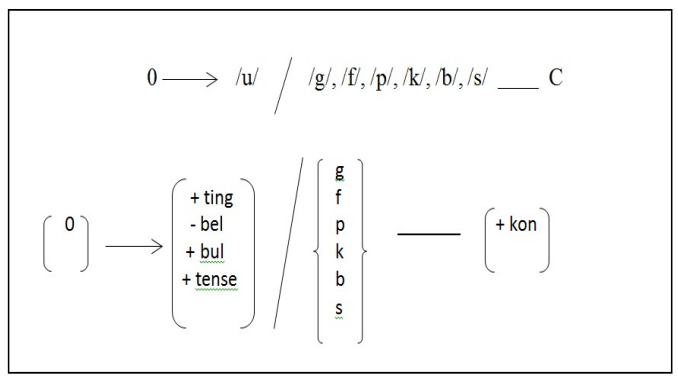

Tabel 4

\section{Keterangan :}

Kaidah pada tabel 4 di atas dapat dijelaskan bahwa terdapat penambahan fonem /u/ setelah bunyi konsonan /g/, /f/, $/ \mathrm{p} /, / \mathrm{k} /, / \mathrm{b} /$, , s/ yang diikuti bunyi konsonan setelahnya.

\section{e) Subsitusifonem $/ \mathbf{1} / \operatorname{menjadi} / \mathbf{r} /$}

Data 5 diatas terdapat proses fonologis subsitusi fonem /1/ menjadi fonem / $\mathrm{r}$, dikarenakan dalam sistem fonologi bahasa Jepang tidak mengenal bunyi lateral /1/. Sehingga menyebabkan fonem /1/ akan digantikan dengan fonem $/ \mathrm{r} /$ ketika mengadaptasi kata-kata bahasa Inggris yang terdapat fonem /1/. Proses subsitusi fonem /1/ tersebut berfungsi untuk menghindari adanya bunyi lateral pada kata bahasa Jepang. Kaidah fonologis subsitusi segmen tersebut adalah sebagai berikut:

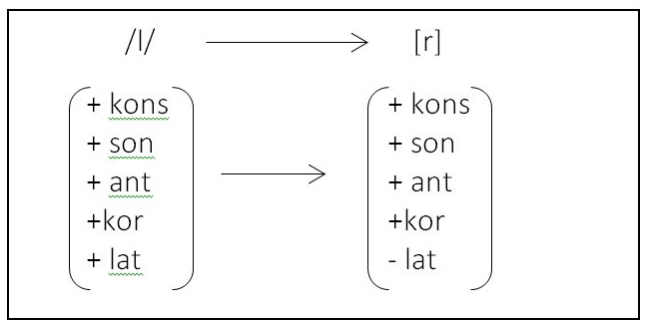


Izumi, Volume 7 No 2, 2018

e-ISSN: 2502-3535, p-ISSN: 2338-249X

Tersedia online di http://ejournal.undip.ac.id/index.php/izumi

\section{Tabel 5}

\section{Keterangan :}

Kaidah pada tabel 5 dapat dijelaskan bahwa bunyi /1/ diubah menjadi bunyi [r].

\section{f) Substitusi fonem /v / menjadi /b/}

Berdasarkan data 6 terdapat proses fonologis substitusi fonem $/ \mathrm{v} /$ menjadi fonem $/ \mathrm{b} /$, dikarenakan dalam sistem fonologi bahasa Jepang tidak mengenal fonem $/ \mathrm{v} /$. Sehingga menyebabkan fonem /v/ akan digantikan dengan fonem /b/ ketika mengadaptasi kata-kata bahasa Inggris yang terdapat fonem $/ \mathrm{b} /$. Proses subsitusi fonem /b/ tersebut berfungsi untuk menghindari adanya bunyi $[\mathrm{v}]$ pada kata bahasa Jepang. Kaidah fonologis subsitusi segmen tersebut adalah sebagai berikut:

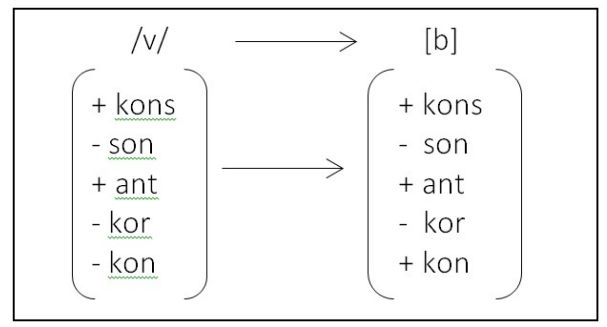

Tabel 6

\section{Keterangan :}

Kaidah pada tabel 6 di atas dapat dijelaskan bahwa bunyi /v/ berubah menjadi bunyi [b] di posisi manapun.

\section{g) Penambahan segmen /i/}

Berdasarkan data 7 terdapat penambahan fonem /i/ pada kata bahasa Inggris yang berakhiran konsonan / $/ \mathrm{g} /, / \mathrm{j} /$. Proses penambahan segmen /i/ di atas terjadi dikarenakan dalam sistem fonologi bahasa Jepang tidak mengenal sistem pelafalan bunyi palato alveolar di akhir kata. Dan juga dalam sistem fonologi bahasa Jepang yaitu mengenal sistem silabel terbuka atau suku kata yang selalu berakhiran dengan bunyi vokal. Sehingga menyebabkan fonem $/ \mathrm{g} /, / \mathrm{j} / \mathrm{jika}$ berada di akhir kata maka akan ditambahkan dengan fonem /i/. Proses penambahan segmen tersebut berfungsi untuk menghindari adanya bunyi konsonan pada akhir kata dalam Bahasa Jepang. Kaidah fonologis penambahan segmen tersebut adalah sebagai berikut:

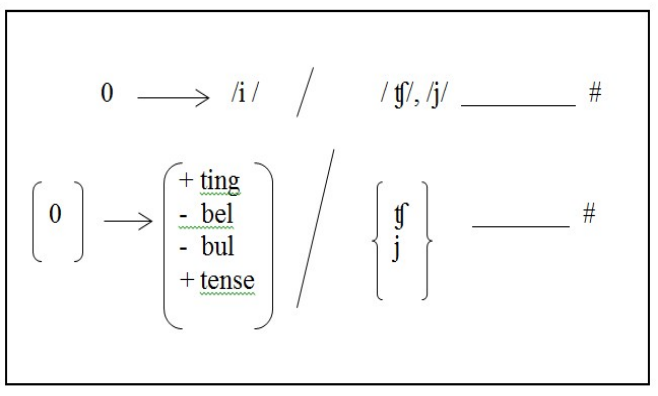

Tabel 7

\section{Keterangan :}

Kaidah pada tabel 7 di atas dapat dijelaskan bahwa terdapat penambahan fonem /i/ diposisi akhir setelah konsonan $/ \mathrm{t} /$, dan /d/ yang yang di dahului oleh bunyi konsonan.

\section{h) Substitusi fonem $/ t /$ menjadi fonem /c/}

Berdasarkan data 8 terdapat proses fonologis substitusi fonem $/ \mathrm{t} / \mathrm{menjadi}$ fonem /c/, dikarenakan dalam sistem fonologi bahasa Jepang tidak mengenal bunyi [ti] tetapi hanya terdapat bunyi [ci]. Sehingga menyebabkan suku kata dari bahasa Inggris yang berbunyi [ti] akan digantikan dengan bunyi [ci] ketika mengadaptasi kata-kata bahasa Inggris yang terdapat bunyi [ci]. Proses subsitusi di atas berfungsi untuk menghindari adanya bunyi [ti] pada kata bahasa Jepang. Karena bunyi tersebut tidak terdapat dalam sistem fonologi bahasa Jepang. Kaidah fonologis subsitusi tersebut adalah sebagai berikut: 


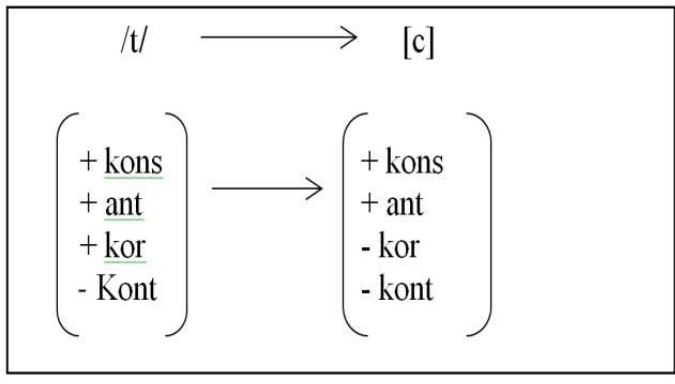

Tabel 8

\section{Keterangan :}

Kaidah di atas dapat dijelaskan bahwa bunyi /t/ berubah menjadi bunyi [c]

\section{SIMPULAN}

Berdasarkan pembahasan di atas, maka peneliti dapat memberikan kesimpulanyang didasarkan pada rumusan masalah yang diangkat sebelumnya. Kesimpulan yang dapat diambil peneliti pada analisis proses penyerapan bahasa Inggris ke dalam bahasa Jepangyaitu ditemukandelapan kaidah fonologis yang terdiri dari : (1) proses penambahan segmen $/ \mathrm{u} /$ di akhir kata, (2) penambahan segmen /o di akhir kata, (3) penambahan segmen /u di tengah kata, (4) penambahan segmen /o/ ditengah kata, (5) substitusi fonem /1/ menjadi /r/, (6) substitusi fonem /v/ menjadi /b/, (7) Penambahan segmen /i/, (8) substitusi fonem /t/ menjadi fonem $/ \mathrm{c} /$.

Proses perubahan fonologis pada penyerapan bahasa Inggris ke dalam bahasa Jepang tersebut yaitu didasarkan pada perbedaan internal pada sistem fonologi yang terdapat dalam bahasa Inggris dan bahasa Jepang sendiri.Pada sistem fonologi bahasa Jepang tidak mengenal sistem silabel terbuka, sehingga hampir dari keseluruhan kata yang diserap dari bahasa Inggris ke bahasa Jepang akan disesuaikan dengan sistem fonologi yang ada pada bahasa Jepang.

\section{DAFTAR PUSTAKA}

Giovanni. (2013). “analisis perubahan makna kata-kata serapan (gairaigo) bahasa Jepang yang berasal dari bahasa Inggris". Skripsi Fakultas Ilmu Budaya Universitas Sumatera Utara.

Harahap, Bachtiar. (2006). Kamus Kata Serapan Bahasa Jepang. Jakarta : Gramedia Pustaka Utama.

Nafisah, Saidatun. (2017). "Proses Fonologis dan pengkaidahannya dalam Kajian Fonologi Generatif".

Perwira, Yanuarria Kukuh. (2016). "Proses Penyerapan Bahasa Belanda ke dalam Bahasa Jawa (Sebuah Kajian Fonologi Generatif Transformasional)". Tesis Fakultas Ilmu Budaya Universitas Diponegoro.

Schane, A Sanford. (1992). Fonologi Generatif. Jakarta : Gelora Aksara Pratama.

Sudaryanto. (1993). Metode dan Analisis Teknik Analisis Bahasa: Pengantar Penelitian Wahana Kebudayaan secara Linguistik. Yogyakarta : Duta Wacana University Press.

Sudjianto, dan Ahmad Dahidi. (2007). Pengantar Linguistik Bahasa Jepang. Jakarta: KBI

Sunarni N, Jonjon Johana. (2010). Morfologi Bahasa Jepang. Sumedang : Universitas Padjadjaran.

Sutedi, Dedi. Dasar-dasar Linguistik Bahasa Jepang.Bandung : Tim HUP

Yusuf, Suhendra. (1998). Fonetik dan Fonologi.Jakarta : Gramedia. 